Session 2530

\title{
Assessing Engineering Teaching Kits for Middle School Students
}

\author{
Larry G. Richards, Jesseca Flaherty, Jennifer Cunningham \\ University of Virginia/the Rochester Institute of Technology/Charlottesville High School
}

\begin{abstract}
At the University of Virginia (UVA), we have been developing engineering teaching kits (ETKs) to introduce engineering design to middle school students. This paper describes our strategies for assessing these ETKs and evaluating our entire program. So far, we have three sources of assessment information: classroom observations, teachers' reactions to these materials including their willingness to use ETKs, and formal assessments conducted during a teachers' workshop held at the University of Virginia in August of 2003. This paper reports the results of these assessments, and their implications for our continued work in this area.
\end{abstract}

\section{Introduction}

The Virginia Middle School Engineering Education Initiative (VMSEEI) has been developing ETKs to introduce middle school students to engineering concepts and techniques. Each ETK emphasizes the engineering design approach to problem solving. We identify topics from science, math, and technology that have interesting engineering applications, and then help students learn science and math in the context of engineering design. Each ETK includes real-world constraints: budget, cost, time, risk, reliability, safety, and customer needs and demands, and each involves a design challenge that requires creativity and teamwork. ${ }^{1}$

This project involves faculty and students at the University of Virginia (from both the Curry School of Education and the School of Engineering and Applied Science), teachers and students in local middle schools, and administrators and parents. So far over 150 middle school students have used these materials. Thirty-seven fourth-year Mechanical Engineering students participated in this project last year as part of a new senior design sequence; this year thirty-five new undergraduate students are involved. Eight middle school teachers have used these ETKs in classes so far, and, in August 2003, seventeen middle school teachers came to a workshop at UVA to evaluate our products and project.

\section{The First Three ETKs:}

In our initial Senior Design class, six teams undertook projects aimed at developing ETKs. Three were ultimately successful; our criterion for success was that the lesson plans were actually used in a middle school classroom. Three other teams achieved acceptable lesson plans, but failed to develop a meaningful Design Challenge. The two defining attributes of engineering teaching kits are: (1) they realize the guided inquiry approach to teaching science and math, ${ }^{6,7,8}$ and (2) they teach the engineering design approach to problem solving. $5,9,10$

"Proceedings of the 2004 American Society for Engineering

Education Annual Conference and Exposition

Copyright (C2004, American Society of Engineering Education” 
The successful ETKs dealt with submersible vehicles, model solar cars, and brain perfusion. The other ETKs focused on design for sustainability, simple machines, and engineering materials. The last two have been continued into this year's class, and both will be tested in schools this semester.

Submersible Vehicles - "Under Pressure": This team's lesson plans introduced the concepts of density, mass, volume, buoyancy, drag, propulsion, and the role of engineering materials. Middle school students initially experiment with different objects to determine why they float or sink. They then explore the concepts of buoyant force, drag, and propulsion. Building upon this knowledge, teams of middle school students design and build their own underwater vehicle using a variety of materials and components available to them. Each team separately tests their final vehicle and evaluates its performance. The students are asked to document how each concept in the lesson plans influenced the design of their submarine. On the final day of the ETK, all of the teams compete to see whose submarine best satisfies the design criteria: neutral buoyancy and directed motion through the tank.

Under Pressure was our first team to test their ETK in an actual school setting. ${ }^{2}$ These students worked with two science classes at Walker Upper Elementary School in Charlottesville prior to and during the trial of their ETK. The lesson plans included team activities and individual assessments. Two students from the Curry School helped develop the final materials for the class. The activities included authentic embedded assessments for both teams and individuals. The teachers were asked for their comments. And finally team members and an education graduate student observed the class.

Solar Car Design - "Ra Power": Using predetermined supplies, teams design and build an electric model car powered by energy derived from light. Students learn basic concepts and principles of mechanical and electrical energy including how to measure each and how to relate one to the other. They also learn the fundamental principles of statics and dynamics (friction, drag, acceleration, constant velocity, and motion). Based on this knowledge, student teams design cars, assess their performance, and predict power needs. They also test solar panels, compare the results to the estimated power needs of their cars, and determine the parameters for the design of their cars. The design challenge is to build a solar car designed to pull a load, and compete of other teams to see which team pulls the most weight. The teams have a budget and each component they might use has a cost. The budget is structured so the teams cannot buy the best of everything, so they must make tradeoffs and realize the best design subject to cost constraints.

Brain Tumor Perfusion - "Brainiacs": This ETK introduces students to the biological, chemical, mechanical, and medical aspects of perfusion/infusion brain tumor treatment. Student teams investigate the nature and treatment for this type of tumor, and devise a treatment plan based on their research. Physical models of the brain and the use of a mechanical syringe simulate the treatment (by infusing fluids into a tumor). The students design a device to deliver a measured amount of fluid to a particular location in the brain. They then assess the success or failure of their treatment. This ETK also covers the social, cultural and personal impacts of this disease.

"Proceedings of the 2004 American Society for Engineering Education Annual Conference and Exposition 
These three ETKs have been tested in local schools and summer programs at UVA. In addition to Under Pressure, the Solar Car ETK was tested at Walker and Sutherland Middle School, and the Brainiacs ETK was also used at Walker. However due to scheduling problems, the Brainiacs ETK was not initially taught by its development team. All three ETKs were also used with middle school students in a summer enrichment program at UVA and with high school students in a summer Introduction to Engineering program.

\section{Assessments}

Three types of assessment have been used throughout the ETK program. Our initial assessments are relatively informal, but they are capable of providing the type of information we need at this stage of ETK development. ${ }^{11,12,13}$ We want to know what middle school teachers think of what we have done so far, and what they think we should pursue in the future. Teachers' reactions and suggestions are important for insuring the acceptance of ETKs into middle school classes. Thus these assessments are our first level of product testing.

Classroom observations: The UVA students who created the ETKs taught them in the middle school classrooms. For each class period, part of the team did the actual teaching, while the reminder observed and took notes. The notes included information on how the middle school students responded to the ETK activities, how well the UVA students presented the material, any problems that developed, and other observations that might help when teaching the next time around.

Teachers' Reactions: Our second assessment process involves interviewing teachers who have experienced our ETKs. Some of these teachers have had UVA students come into their classrooms to teach the lesson plan, whereas others have used the ETK materials and conducted it on their own. So far, three teachers have used ETKs without our teams present. Ginger Moored conducted the submersible vehicles in the preengineering program at Dunbar High School, Jennifer Cunningham has taught all three ETKs in enrichment programs, and Arlene Terrell has taught both Under Pressure and Ra Power at Walker Upper Elementary School in Charlottesville. We have received extensive feedback from all three. Ginger managed several ingenious modifications of the submersible vehicles ETK to conduct it with minimal cost. Jennifer wrote her Master's Thesis based on this project. ${ }^{3}$ Arlene has returned our lesson plans with many suggestions and annotations. She has helped us identify where we need substantial elaboration.

Teachers' Workshop: In August of 2003, a workshop was held at the University of Virginia for teachers interested in using our teaching kits. Seventeen teachers attended representing middle schools in the City of Charlottesville, the counties of Albemarle, Fluvanna, and Orange, as well as Richmond, Roanoke, and Washington D.C. (Dunbar Pre-Engineering). In addition, UVA students and faculty from the schools of engineering and education participated, as well as a visitor/observer from Pennsylvania State University. The workshop allowed us to demonstrate the three mature ETKs and discuss others already under development. The teachers provided detailed assessments of these

\footnotetext{
"Proceedings of the 2004 American Society for Engineering Education Annual Conference and Exposition Copyright @2004, American Society of Engineering Education”
} 
Session 2530

ETKs, and of the Virginia Middle School Engineering Education Initiative (VMSEEI) approach. We also solicited ideas for ETKs we might develop in the future.

\section{Overall Evaluation of VMSEEI Approach}

We obtained rich and varied feedback from the teachers about our overall approach and the individual ETKs. This section includes selected answers to the survey items about the overall VMSEEI approach. Verbatim survey results for the three ETKs (Under Pressure, Brainiacs, and Ra Power) and the Overall VMSEEI Assessment are given in Appendices. We will highlight some of the key findings here, but the detailed feedback included in the Appendices has resulted in substantial improvement of the ETKs.

Overall impression: The teachers felt that we had done an excellent job in creating relevant, challenging instructional materials. They liked the clear lesson plans, and their reliance on inquiry and investigation. They felt that direct application of science and math concepts to real life situations created excitement and made learning authentic. A theme echoed by several teachers at the workshop is that a major benefit was "The presence of University students in the classroom, providing wonderful role models for the middle school students"

The engineering design approach: For us the key question was "Does engineering design seem to be a reasonable way to introduce science and math concepts and procedures to your students?" We were delighted that all of the teachers answered "Yes". A few added comments:

- Learning by discovery and invention are proven to be some of the best ways to learn.

- I would like to see the enhancement of the math applications so kids can see the relation of math with science to an even greater degree.

Additional features: To enhance the ETKs, teachers suggested quizzes and rubrics (for embedded assessment), supply lists (this has proven to be crucial for teachers using the ETKs without our students present.), and anything that creates a challenge, a goal, and a "prize" at the end of the lesson.

Media: Most teachers want a printed version of the ETK. However CD and Web Page distribution were also popular. Most teachers wanted all three. Many teachers felt that we need to do more to educate them about our approach and materials. This might include staff development days, institutes and workshops, seminars and talks, and accessible and obtainable support. A website with a "frequently asked questions" page would be a helpful vehicle for maintaining contact between teachers and VMSEEI. From their side, teachers felt that school districts need to support their people in working cooperatively with other groups and schools.

Time Frame: How long should an ETK be? The range of answers was from 5 days to 2 weeks. In general our target length of five days seems about right. But teachers felt we should allow adjustability to expose the kits to the entire school population (to accommodate different grade and ability levels), and we should create in-depth lesson

\footnotetext{
"Proceedings of the 2004 American Society for Engineering

Education Annual Conference and Exposition

Copyright $@ 2004$, American Society of Engineering Education”
} 
plans with three length options (short, middle, and long). These results affirm the value of our modular approach. One or two week units can be easily integrated into existing science and math courses.

\section{Summary:}

Middle school teachers were uniformly positive in their reactions to our approach. Their enthusiasm is very encouraging. Perhaps the novelty and variability of ETKs is a primary initial benefit for the schools. Another benefit involves the presence of engineering students in classrooms. Several teachers noted how inspiring and motivating their involvement was for the middle school students.

However there were some concerns about the ETKs. Teachers want much more detail and background in the ETKs. They also want professional development activities focused on ETKs. We plan to follow up with more extensive teacher education initiatives including workshops. Several teachers asked for a video showing how the ETKs can be used in the classroom. They also want support, and access to help. Some teachers were concerned about the availability and affordability of materials and equipment.

Finally, middle schools have been our target audience. But teachers wondered "Is there a link from the middle school activities to the next level for high school students?" and a few are interested in these activities for the $5^{\text {th }}$ grade. There is a desire for flexibility in the implementation of ETKs.

\section{Assessment of Individual ETKs:}

The Appendices contain verbatim responses from the teachers regarding each of the ETKs. We presented fairly complete responses to illustrate the range and types of answers one gets to these types of questions. Ratings and yes/no items do provide useful input, but at this stage in our development, we wanted candid and critical assessments. For both Under Pressure and Ra Power the teachers felt the ETK contained sufficient information for them to use it in their classes, but for the Brainiacs ETK, they were less sure. Brainiacs was the only ETK not taught by members of its development team. The other two ETKs benefited from the team members teaching their material and then revising their lesson plans based on their experiences in the classroom.

\section{Suggestions for Future ETKs}

Our final workshop task focused on the next phase of VMSEEI. Each teacher individually generated a list of possible topics for future ETKs. After completing their lists, we formed three groups and asked them to develop their top three candidates for future ETKs. These lists provided the basis for this year's senior design class to start their discussions of possible topics. Eight new teams are now developing ETKs. Several are pursuing topics identified in the Summer Teachers' Workshop: projectile motion (Catapults In Action), wind power (Alternative Energy Resources), and structural engineering and load-bearing structures (Destructural Mechanics). We also have an individual student working with an after-school club on rockets and aerodynamics, and

\footnotetext{
"Proceedings of the 2004 American Society for Engineering Education Annual Conference and Exposition Copyright $@ 2004$, American Society of Engineering Education"
} 
Session 2530

another developing a General Chemistry ETK. We plan to continue this project next year, and will have our third set of ETK teams on-board in the fall.

Acknowledgements: VMSEEI is supported by a gift from the Payne Family Foundation, and a grant from the National Science Foundation through their Bridges to Engineering Education Program (NSF-EEC-0230609).

\section{References}

1. Richards, L.G., Laufer, G. and Humphrey, J.A.C., Teaching Engineering in the Middle Schools: The Virginia Middle School Engineering Education Initiative $32^{\text {nd }}$ ASEE/IEEE Frontiers in Education Conference, November 6-9, 2002, Boston, MA.

2. Kraines, A., Klanian, K.L., Peirce, L., Waters, E., Gluchowski, K., Janezic, K., Labrie, J., Cunningham, J., Bart-Smith, H., and Richards, L.G. "The Virginia Middle School Engineering Education Initiative: using a senior design course to develop engineering teaching kits." $33^{\text {rd }}$ ASEE/IEEE Frontiers in Education Conference, November 5 - 8, 2003, Boulder CO.

3. Cunningham, J.L. (2003) Factors Influencing Students Attitudes, Knowledge, and Interest in the Field of Engineering and Recommendations for Improvement: a study of inquiry-based middle school engineering teaching kits Curry School of Education, University of Virginia, Charlottesville, VA.

4. Pearson, G. and Young, A.T., (eds) (2002) Technically Speaking: why all Americans need to know more about technology National Research Council: National Academy Press, Washington, D.C.

5. Massachusetts Department of Education, (2001) Massachusetts Science and Technology/Engineering

Curriculum Framework, Malden, MA

6. Bransford, J. D., Brown, A. L., and Cocking, R.R. (eds), (2000) How People Learn: Brain, Mind, Experience, and School, Expanded Edition. National Research Council: National Academy Press, Washington, D.C.

7. Thier, H. D. and Daviss, B., (2001) Developing Inquiry-Based Science Materials: a Guide for Educators Teachers College Press, New York.

8. Brooks, J.G., and Brooks, M.G., (1999) In Search of Understanding: The Case for Constructivist Classrooms. ASCD

9. Dunn, S. and Larson, R. (1990) Design Technology: Children's Engineering The Falmer Press, Bristol, PA.

10. Wiggens, G. and McTighe, J., (1998) Understanding by Design Merrill /Prentice-Hall, Upper Saddle River, N.J.

11. Angelo, T. A. and Cross, K. P., (1993) Classroom Assessment Techniques: A Handbook for College Teachers, Second Edition, Jossey-Bass, Inc. San Francisco, CA.

12. ASEE (1998) How Do You Measure Success? Designing Effective Processes for Assessing Engineering Education, American Society for Engineering Education, Washington, D.C.

13. Pelligrino, J.W.., Chudowsky, N., and Glaser, R. (eds), (2001) Knowing What Students Know: the Science and Design of Educational Assessment. National Research Council: National Academy Press, Washington, D.C.

"Proceedings of the 2004 American Society for Engineering

Education Annual Conference and Exposition

Copyright (C2004, American Society of Engineering Education” 
Session 2530

\section{Biographic Information}

LARRY G. RICHARDS is an Associate Professor in the Department of Mechanical and Aerospace Engineering at the University of Virginia. He teaches a senior design course on the Design and Implementation of Engineering Teaching Kits, and directs the Virginia Middle School Engineering Education Initiative (VMSEEI).

JESSECA FLAHERTY is a senior in Mechanical Engineering at the Rochester Institute of Technology. She was an Intern at the University of Virginia in the fall semester of 2003, and worked with VMSEEI and the Senior Design class developing ETKs.

JENNIFER CUNNINGHAM is a Chemistry teacher at Charlottesville High School. She has her B. S. in Chemistry from UVA and a Master's Degree in Science Education. She worked with student teams developing the first generation of ETKs and has taught all of the initial three. 


\section{Appendix I: Submersible Vehicles - Under Pressure}

\section{What features of this ETK did you like?}

- Its similarity to the skills needed re: aircraft/aerospace design

- Hands on and visual

- Experimental method of learning

- Tactile and iterative nature of the design

- Creative ways of getting the basics across

- Straw project - Super!

- Materials were not too expensive and easily accessible - disregarding the tank

- Kids excited about the end product of the project

- Diversity of designs

- Specific SOL linkage

- Very concept / problem based it would definitely catch a kid's interest. The engineering design process worksheets would really lead students through the work of engineers

- Principles are not too complex for students of varying levels

- The way the ETK is designed to check the student's understanding throughout the unit

- Intro to scientist vs. engineer

- Concepts of density were very effective

\section{What features of the ETK did you dislike?}

- None!

- Material might be a problem with multiple classes

- 7 answers re: the expense of the tank or access to one

- Prep / set up time

\section{How can this ETK be improved?}

- Make a set of set of cheap, easy instructions for a "cheap" easily constructed tank

- I would like to see more application to the units being taught in class as well as some formal assessment

- More time to allow for presentations at the end of the project so that the students can demonstrate what they learned

- Detailed ordering information

- Will you provide a support system for teachers?

- Be sure to add the coke vs. diet coke comparison, which was very effective! You did this with us at walker and the kids "got it"

Are the lesson plans and student worksheets clear and easily readable?

- 14 answers of Yes

Do you have any suggestions to improve the layout?

- 9 answers of No

- Have forms and numbers available for ordering the motors and other materials

Are the materials in the ETK arranged logically?

- 14 answers of Yes

Is there anything included in the ETK that is not necessary?

- 12 answers of No

- 1 answer of Don't know until I use it

- 1 answer of Yes

○ Homework - the kids seem "overloaded" with other subjects.

\section{Is there anything that should be added to this ETK?}

- Overview video for teachers on the subject matter

- Time to "seminar" with other classes engaged in the same project (student teaching student opportunities)

- Where to get the motors

"Proceedings of the 2004 American Society for Engineering

Education Annual Conference and Exposition

Copyright (C2004, American Society of Engineering Education” 
- Be sure the coke vs. diet coke demo gets in there!

Do you cover the topics of the ETK in your classes?

- 9 answers of Yes: Surface area / floating, buoyancy, density, mathematics, grade 6 SOL, scientific method, lift, drag, thrust, gravity

Does this ETK adequately address Virginia SOL topics?

- 10 answers of Yes: Scientific method, energy SOL, 6.1, 6.2, 6.5, density, material, scientific inquiry, experiment, and design

How well are the basic science concepts presented in the material leading up to the design project?

- 14 answers of Very or Extremely well

Do you think your students will come away from the unit with a better understanding of the science content?

- 14 answers of Yes

How effectively do you think the design project requires the students to apply what they have learned?

- 12 answers of Very effective

Does this ETK include sufficient problem solving activities?

- 12 answers of Yes

What modifications would you suggest to improve the teachability of this ETK?

- Is there a smaller scale that this could be done on to improve the portability of this ETK?

- Maybe an overview of video

- Water Tank! How does a school acquire a water tank? How big does it need to be?

- Have teachers familiarize their students with Newton's three laws

Is the information provided sufficient for you to use this ETK in your classes?

- 11 answers of yes 
Session 2530

\title{
Appendix II: Model Solar Cars - Ra Power
}

\author{
What features of this ETK did you like? \\ - Lots of hands on activity - visible \\ - Competition \\ - Solar Energy, Friction, Torque \\ - A simple ETK that any teacher can do anywhere \\ - Very applicable to current SOL's \\ - Easy to implement \\ - Somewhat open ended \\ - Not terribly time consuming \\ - Cost constraints \\ - Kids excited about building the cars \\ - Doesn't require a lot of background to present \\ - Teaches different roles of scientists and engineers \\ - Problem and inquiry based \\ - Ability to link it to math objectives (formulas, gravity, etc) \\ - Creativity encouraged \\ - Problem solving \\ - I like the emphasis on power rather then speed \\ - Basic solar power info \\ - Good design components \\ What features of the ETK did you dislike?
}

- The demonstration vehicle didn't "work"

- Lacking in the story element

- More info on the subject (video)

- I would like to see students build multiple cars and then compare each car and assess the fastest, strongest, and best over all.

- Reliability of photocells seemed to be problematic

- The objective for this ETK could be clearer. For example rather then merely saying the objective is to "understand how solar cells convert light energy to electric energy" the teacher should tell us how this will be accomplished.

\section{How can this ETK be improved?}

- Be sure that the demonstration car works

- Set the exercise in space or mars or the moon. Figure out how much the vehicles could haul under different gravities. Include more about the photoelectric effect.

- I'd like to see all students build the base (not just high school)

- It would be very "cool" to include pictures/model or trip to the UVA solar car and ship...

- Select different solar cells / light sources

- More in-depth information for teacher preparation

- Unlike the other two modules, this module (ETK) wasn't centered on a "problem" - brain tumor, sunken ship, etc. It was much more of a straightforward engineering project. I'd suggest creating a context around the ETK. For example, you might create a scenario in which all of the earth's fossil fuels have been depleted and although these are "mini" solar powered vehicles for personal use scientists and engineers are trying to find a means of transporting large supplies using a larger truck or trailer tractor powered by solar energy

- More teacher friendly for those of us who don't have as much back ground information

- Information on where materials could be purchased

- Will you provide a support system for teachers?

- Discuss how a motor works!

"Proceedings of the 2004 American Society for Engineering

Education Annual Conference and Exposition

Copyright $@ 2004$, American Society of Engineering Education" 
Are the lesson plans and student worksheets clear and easily readable?

- 12 answers of Yes

- Have used them at a really good level for students in middle school

Do you have any suggestions to improve the layout?

- 6 answers of No

○ Not with out using it in class

- Include video clip, pictures, articles about real solar car technology and future plans/designs

- More technical info for teachers to have on hand to clarify info

- Include more diagrams. Ex energy train.

- Make sure teachers have info about the tools used. Ex voltmeter, solar cells, motors

- Overview of the material in the beginning

Are the materials in the ETK arranged logically?

- 11 answers of Yes

- Needs intro and motor intro info

Is there anything included in the ETK that is not necessary?

- 11 answers of No

Is there anything that should be added to this ETK?

- More info on photoelectric and space/solar

- Any specs that may be wanted for the cars unless you wanted it completely open ended

- Chemistry of the photovoltaic cell to show energy conversion

- Trouble shooting e-mail source. i.e.: what if wires come unhooked? Duct tape?

- AV

- Catalogs and price lists

- Post assessment

- More real life applications

- Alternative car types other than Legos

- Not with out using it in class

- Video on solar technology

- Post assessment journal writing to record their thoughts/ideas and process; have students reflect during this process

Do you cover the topics of the ETK in your classes?

- Doesn't everyone cover renewable resources?

- 13 answers of Yes

- Technology classes (6-8), energy, conservation of energy, friction, from a math perspective, solar energy, conversions, variables, from an aero perspective

- No torque or solar cells

Does this ETK adequately address Virginia SOL topics?

- 3 answers of Uncertain

- 8 answers of Yes

- 1 answer of No - re: high school

How well are the basic science concepts presented in the material leading up to the design project?

- 10 answers of very well

- I don't think you would be out of line to include the equations for force or other things

- Students obviously have to have some background knowledge though to be successful in my opinion; the teachers will give background information before the lesson is used

- Students need to see how these basic science concepts apply in new situations

- Need more info on motors, sun rays (radiation) historical look at energy (spec. solar) and drag, friction

"Proceedings of the 2004 American Society for Engineering

Education Annual Conference and Exposition

Copyright (C2004, American Society of Engineering Education” 


\section{Do you think your students will come away from the unit with a better understanding of the science content?}

- 13 answers of Yes

$\bigcirc \quad$ This will help them think of realistic aspects of physics

- Relate it to future considerations of solar energy in our economic / politics

- The info may or may not be new to them. In either case it provides a challenge for the students to extend themselves and apply scientific and engineering principles to real life situations

- I'd like to see follow up presentation where teams demonstrate learning

- As long as the concepts are reinforced after the activity with some types of assessment

How effectively do you think the design project requires the students to apply what they have learned?

- 9 answers of very effectively

- It possibly could be improved by a specific goal (something like be able to move a given weight a given distance or a given surface)

- Especially when they can test and redesign

- This project is about mechanical energy not so much energy conversion

\section{Does this ETK include sufficient problem solving activities?}

- 9 answers of Yes

- Perhaps incorporate a little more about how an effective solar cell might be hindered by other factors...such as drag, etc

- I especially like the inclusion of a budget restraint

$\circ$ For students in the $6^{\text {th }}$ grade

- I would like to see more. (eg) what type of light best powers cell? Why?

- 1 answer of No

- It needs more tradeoffs, ala Under Pressure

\section{What modifications would you suggest to improve the teach-ability of this ETK?}

- A reliable energy source

- Have all students build base/design car

- Teach-ability is excellent...

- Include detailed background info on key concepts and the use of tools for the teacher who may not have had experience with these materials

Is the information provided sufficient for you to use this ETK in your classes?

- 10 answers of Yes

- Provide a catalogue from which to order parts etc.

- Provide suggestions for effective materials - ie: "use a halogen light and not incandescent or florescent light... use these Lego sets, etc"

- I would have to use it to be certain

- More in-depth info for teacher

- Ordering info

- How to use tools.

- Make it user friendly, teachers don't have time to hunt around for this stuff.

- I called different companies to find out what types of bulb to use with solar cells, how far to hold them above they cells, etc.

- Basic info that you know and the teachers may not know

\section{Extra notes}

- I'd love to actually see the PowerPoint on electric motors to see if it's age appropriate and an actual learning experience - do kids come away with the actual knowledge of how a motor works.

- I like emphasis on power rather then speed!

- Interesting question: Are solar powered transfer trucks possible?

\footnotetext{
"Proceedings of the 2004 American Society for Engineering

Education Annual Conference and Exposition

Copyright (C2004, American Society of Engineering Education"
} 
Session 2530

\section{Appendix III: Brain Perfusion - Brainiacs}

\section{What features of this ETK did you like?}

- Hands on

- Open ended

- Problem and inquiry-based

- Not thought of as "conventional engineering"

- Very true to actual technique

- Jell-O Brains are Cool

- Blending of sciences and engineering

- Real life example

- Biology-based interesting subject

- Imaging and exploratory surgery techniques

- Feedback designing

- Motivating and student engaging activity

- Staining application

- Introduces problem solving in cross discipline setting

- Looks at more then one concept (solubility, problem solving, surgery techniques, etc)

\section{What features of the ETK did you dislike?}

- The chemicals may be too harsh for middle school and elementary age students

- Suggestion of finger nail polish remover in place of acetone

- Many concepts were involved, some peripherally, that could blur the focus or distract the student from the principle goals

- Preparation of Jell-O brains

\section{How can this ETK be improved?}

- Add field trips to look at equipment being used in the field

- Find a replacement for the acetone

- More tumor/medicine options for tough tumors

- Variable sizes of tumor and placement of tumor in different lobes.

- Make it cheaper! You'd need a sizable Jell-o budget to serve all the students in my classes! *Try using slime instead of Jell-o (cheaper). Just add extra borax to stiffen it up...

- Tumor locating techniques appear to need improvement

- Video of the process of brain surgery

- Catalogue references of where to buy materials etc

- Care should be considered with the presentation for students who have personal experience with brain tumors

- Supplement the unit with lessons on solubility, flow rate, scientific method, etc

- Compare and Contrast the roles of Doctors and Engineers

- The crank design portion should be introduced earlier and presented more clearly

- There are not enough math concepts to justify time used in class

- More information on blood brain barrier, functions of the sections of the brain, and names of scientists and engineers with information of their discoveries - in case we have to prod the kids for answers

- List of objectives and SOL's

- How will teachers afford the material?

- Ingredients and procedures for making the Jell-O mold - more clearly explain the two layer idea

- Will you provide a support system for the teachers?

- Talk about radiation

"Proceedings of the 2004 American Society for Engineering

Education Annual Conference and Exposition

Copyright $\odot 2004$, American Society of Engineering Education" 
Are the lesson plans and student worksheets clear and easily readable?

- 12 answers of Yes

- Avoid SWBAT and others, write everything out

Do you have any suggestions to improve the layout?

- 8 answers of No

- Separate student and teacher sections

Are the materials in the ETK arranged logically?

- 13 answers of Yes

Is there anything included in the ETK that is not necessary?

- 10 answers of No

- Concepts on brain and cancer may need to be "streamlined"

Is there anything that should be added to this ETK?

- Further reading / experiments in the area of treatment resulting in brain damage

- Background for the teachers in the areas of new techniques and brain surgery

- Student examination of the scientific method

- Where to get the supplies/costs

- Video of how tumors are located using magnets and possibly treatment of surgery being administered

- Post assessment!

- The suggestion of the students keeping a journal and writing down their thoughts/ideas each time (double sided journal writing)

Do you cover the topics of the ETK in your classes?

- 3 Answers of No

- 2 Answer of Yes

- Indirectly, certainly not in this interesting way

- Not so much with the biological applications as with the chemical or physical.

- We used to (but no longer do) cover some biology concepts. Could be used for Sci. Method.

- Most, some, life science is a better use

- Solubility

Does this ETK adequately address Virginia SOL topics?

- 3 answers of Not sure

- 7 answers of Yes

○ Investigation, Problem Solving, Matter,

- 1 answer of No (regarding math SOL's)

How well are the basic science concepts presented in the material leading up to the design project?

- Very Well

- I will present them well

- Depends on depth of class and their needs

- Looks to be a little scant on what the lobes of the brain do

- Looks ok, but it is hard to say with out having looked at the PowerPoint presentation, a lot depends on that

- Not certain

- Great presentation

- The concepts are aptly presented

- Not strong enough for me - but I was looking for the math component

- The concepts are easy enough for all of the students to be successful in the final project

- Very appropriate

"Proceedings of the 2004 American Society for Engineering

Education Annual Conference and Exposition

Copyright (C2004, American Society of Engineering Education” 


\section{Do you think your students will come away from the unit with a better understanding of the science content?}

- 10 answers of Yes

- The students have little to no exposure to this subject

- The hands on will drive home the ideas

- They will be more directly involved

$\circ \quad$ It will bring cancer treatment alive

- Students may even leave with a desire to learn more

- Yes, but it is hard to tell with no post assessment

- Yes...this is an excellent engineering project because it allows them to design an appropriate solution to a concrete (scientific) situation

How effectively do you think the design project requires the students to apply what they have learned?

- 7 answers of Very effective

- 1 answer of Hard to say

Does this ETK include sufficient problem solving activities?

- 11 answers of Yes

- No because all the solutions were the same

What modifications would you suggest to improve the teach-ability of this ETK?

- If there were some way to make the brain mildly opaque it might help the gross-out/coolness effect.

- I would like to see students go to a hospital and work with actual patients to have a full appreciation.

- Detailed instructions on how to make the syringe holding apparatus out of the PVS pipe.

- A clear tray with light underneath it to illuminate the tumor better

- A video clip of brain surgery

- Post lab reinforcement Q's that reiterate key concepts

Is the information provided sufficient for you to use this ETK in your classes?

- 6 answers of Yes

- 2 answers of Probably; Maybe a bit more background knowledge for teachers

- 1 answer of No; Not enough math content

- 4 answers of Not sure or N/A

\section{Extra notes}

- I loved this unit! Very excited about doing this with my students!

- Very appropriate! This will interest students who are considering medicine and/or engineering and also "connects" various sciences! (life \& physical) 
Session 2530

\section{Appendix IV: Overall VMSEEI Evaluation}

\section{Based on what you learned today, what is your overall assessment of our approach to developing instructional materials?}

- Things that were Good

$\circ \quad$ You all get an $\mathrm{A}+$

- Inclusion of K-12 education

- Current approach is great

- Workable

- Low prep

- Clear lesson plans that incorporate inquiry and investigation

- Integration of Engineering and Education School students in the development process

- University kids come into the classrooms

- Wonderful role models for kids at the middle level

○ Direct involvement of end-user assessment

- Excellent job creating relevant, instructionally challenging instructional materials

- A great way to introduce these concepts

- Wonderful - direct application of concepts to real life situations creates excitement and make learning authentic

- Approach appears to be useful and valuable

- Very effective. It is often to "visualize" using a new curriculum / approach and these hands-on models made it feasible and exciting

- Technique of trying them out several times and making revisions to improve them during the process

- Exploring methods to excite children when using / introducing science

- Peaking the children's interest is a great way to help them learn and remember real life applications

- Super!

- Using the resources you have available to you

- Right direction

- The introduction of the scientific and engineering aspects to be understood before the project begins

- Things that need improvement

0 It seems that the SOLs are an afterthought

- Instead of identifying an objective to be taught and then finding an engineering problem to fit it, that a "cool" idea is thought up and you try to relate it to a SOL.

- "Under Pressure" was the only ETK that was goal oriented

- Keep in mind to look at VA SOLs

- Be sure to relate the ETK to real life

- Daily SOLs met should be documented

- Talk more about the specifics of the activities possible

- The specific experience of the ETK is as important as its content

- $\quad$ Side notes

- Materials should be developed and team taught with local teachers

- Once the teacher understands how to use the kit, their school may wish to purchase the kit

- Important to have teacher input to make sure the flow and objectives work and are realistic for the class

- There's a need for kits that are relevant, unique, and cost free. You might consider compiling a list of kits that are already available to teachers such as those free three ARC (Alb Cty) and toss kits already in schools

- Teachers with varying backgrounds can give feedback from different perspectives

"Proceedings of the 2004 American Society for Engineering

Education Annual Conference and Exposition

Copyright $@ 2004$, American Society of Engineering Education” 


\section{Does engineering design seem to be a reasonable way to introduce science and math concepts and procedures to your students?}

- 15 answers of Yes

- Problem solving will help incorporate what students know into what is possible

- Creativity and problem solving skills used for engineering design seem like a great "spark" or springboard into sci/math concepts

- The general "problem solving" format of engineering design tasks force the student to understand tough scientific and mathematical concepts in a broad way - as skills for practical applications, not facts

- It would be nice if an engineering course was offered in the $8^{\text {th }}$ grade

- Engineering aspects are essential in both science and math

- I like your emphasis on breaking stereotypes especially those that show teams of females in the field

- Learning by discovery and invention are proven to be some of the best ways to learn

- 2 answers of "good but needs more"

- Be sure to align the kits to the SOLs so that it is time well spent and not rushed thru

- I would like to see the enhancement of the MATH applications so kids can see the relation of math with science to and even greater degree

- More so for science then math, it did not appear that the math aspects were a focus, but an after thought

- Most of the ETKs could incorporate math in an applied way that would be incredibly productive to learning.

- How can these units be intro/or filter into another unit as a culmination experience

- There are ways to integrate Language Arts / Literature and History as well

- Even if it isn't included in your units teachers can adapt on their own

- Reading lists to link science and math to language arts and literature

\section{What additional features should we include in the ETKs? For example, should we build in assessment procedures (rubrics, quizzes,...)?}

- 3 answers of Yes

- 6 answers of Pre and/or Post Assessments

If you want, but not necessary

- 5 answers of quizzes

- A good teacher can create these from what you have

- Quizzes tend to discourage the making of creative mistakes

- 8 answers of rubrics

$\circ \quad$ to evaluate student achievement of objectives

- A good teacher can create these from what you have

- Will help those teachers who don't know everything about the subject

- Post Lab questions

- Anything that creates a challenge, a goal and a "prize" at the end of the product for "getting it right"

- Pre Lab articles that acquaint students with topics (eg: brain surgery, solar cars, submarines)

- More Background Information

- Web Links

- Presentations of a formal nature with required components

- Supplementary support materials list

- Reading lists to link science and math to language arts and literature

"Proceedings of the 2004 American Society for Engineering

Education Annual Conference and Exposition

Copyright $\odot 2004$, American Society of Engineering Education" 
- I think this is probably the one area in which the ETKs most need to be improved. Ideally the unit will provide teachers with

$\circ$ A large unit overview that includes the entire ETK's

- Concepts to be learned

- Skills to be employed

- Facts to be learned

- Modifications for activities/labs

- Supply list

$\circ$ Including where to purchase materials and how much they should cost

- Needs to be a clear objective in regard to what the solution to the problem is trying to accomplish

O Ie: Solar cars - a given weight needs to be pulled a given distance

- An overview (video) for the teacher to review the subject matter and also see the kits in action

- Audio visual aids to introduce students to the topic/content

What media would you prefer for receiving ETKs (printed, CDs, Web page, other)?

- 6 answers of Printed

- 8 answers of CD

- 10 answers of web page

- That way material can be printed out as needed

- If printed ETKs will inevitably lead to higher overhead costs

- Keeping media easy to share is best for distribution

- 2 answers of Any

- 2 answer of all possible media (web page, CDs, printed...)

- Could include audio visual representation...

- A web page with CDs available as pay - for full kits with all downloads etc.

$\circ$ It will cost more for schools w/o internet, but may be more practical

\section{What type and level of support do you think needs to be provided for ETKs to be widely used in middle schools?}

- Not Much

- Lessons are clear, easy to follow and implement

- If you include the above mentioned overview video

- Material support

- Personally - I just need to see it once (this could be done on a web page as well) and I can take it from there

- Staff development day like with the Jason Foundation

- The school district needs to support it to let people work cooperatively with other groups/schools

- Adequate teacher training to use ETKs effectively

- It helps to make the teachers more comfortable with new kits

- With possible access to others with specialized expertise

- An e-mail where some teachers could ask questions

- Teacher workshops where the teachers go through the ETKs in a hands-on way, as the students will be doing it. As it was presented at our workshop I could not feel that I could reconstruct it

- Collaboration (thru grants) to purchase items of large cost

- FAQ page online for support

$\circ$ Where students and teachers can ask questions of professional and student engineers

- A community for ETK design and execution would be a great resources, possibly a bulletin board on the website moderated by Prof. Richards 
- Administration and teachers have to be sold on the idea

- They need to see how the units will cover the SOLs effectively

- They also need to know that there won't be an overlap of ETKs

- For example an $8^{\text {th }}$ grader repeating an ETK that he/she did in the $6^{\text {th }}$ grade

- Accessible and Obtainable support

- Resource contact person

- UVA students to introduce the kits to schools

- Teacher set up or breaking down help with kits

- Guest Speaker!

\section{What kinds of activities, programs, tools, or kits do you currently use in your} classes?

- Wide variety

- Lots of hands-on

- $\quad$ Some GEMS

- 2 answers of AIMS

- 2 answers of Lego

- robotics kits

- Merrill Physical Science

- Hands-on equations

- Rockets

- Air balloons

- Running labs

- Cbi's ?

- Books and websites for ideas on object/introductory activities to get the attention of the students - Normally borrowing or buying tools needed for an activity

- Graphic organizers, Games, PowerPoint presentations, Videos, Audio tapes, Music, KWLs, RAFTs, Jigsaw, Multiple instructional strategies

- Guest speakers, field trips, kits from ARC, own supplies from grants, school supplies, I also have an after school science club open to all $5^{\text {th }}$ graders

- Various labs that require a "hodgepodge" of stuff

- 2 answers of Foss electricity kits

- Kits from Flint and Carolina Biological

- Knet's, eyewitness CD's, other education CD's, internet/computer usage, video/laser disk, music

- Look at a lot of Flinn Scientific kits and buy the materials myself

- Building and flying model planes, engine operation, theory of flight, wind tunnels, and computers with CAD programs

\section{Can you give us an example of an excellent kit or unit you currently use (or know} about)?

- Solar Car Kit from VMSEEI

- Josh and Co Submersible kit

- Flinn Scientific

- Carolina blood typing kit

- Chemical reactions kit - from Pitsco??

- Foss electricity kits

- Atom building kit - from Cambridge??

- Forensic science unit

- UVA/Virginia Natural History Museum kits

- Building parallel circuits to effectively wire a house

- Chemical reaction kits

- Acid/Base testing

- Chemical changes

"Proceedings of the 2004 American Society for Engineering

Education Annual Conference and Exposition

Copyright (C2004, American Society of Engineering Education” 
- www.cpo.com

○ This is a great physical science program with a huge math component

- Creation of own kits based on an interest

- Can't afford to buy pricey kits already assembled

- I created/am revising/revising a unit of Forensic Entomology, Botany, and Anthropology basing it on knowledge gained thru a "Bugs, Bones, and Botany" class offered thru VCU

- Dacten? Lego Kits

- Eschee? tessellation kit housed at Albemarle County Resources Center

- "Reasons for the Seasons" kit

- Eyewitness Nature or Science CD

\section{Computer?}

- $\quad$ Yes yes yes !

- 7 answers of Yes

○ but not based solely on the computer

- think about all the times the computers are "down", there needs to be an alternative way of doing the activity if that happens

○ delivering materials, especially background information

- a list of sites that would further describe or allow for interaction with concepts

$\circ \quad$ At the very least offer it as an option

- Science and technology are very similar in many ways

- Could also use

- Web cams

- Conference calling

- Email/chat experts

- Our society is relying more and more on computers and teachers and students need to be sure to stay up to date with current technology and capabilities

- $\quad$ Please develop activities students can use while on the computer

- The Beams Lab has lots of great things students can do on the computer

- At Walker teachers have access about once a month to a set of 25 computers; thus there are enough to go around, just not that often.

- I use a webelements.com website, CD-Rom Ultimate Science Encyclopedia programs, and they are very helpful

\section{Time Frame?}

- Grade 6-2 weeks

- Time for presentations (formal nature) from each group

- Public speaking skills

- Time for additional follow-up assessments to see if the concepts applied were actually learned

- 3 answers of "5 days is about right"

$\circ \quad$ It should be expandable up to 3 weeks (15 days)

- 5 days is a good place to start, but each ETK will be different and the length of time should be able to be adjusted

- Upper Elementary - 6 to 10 days

- Since concepts are new to these students and will need more explaining before the project can actually begin

- 2 answers of " 2 weeks " - For pre-assessments, the process, post-assessments, and evaluation

"Proceedings of the 2004 American Society for Engineering

Education Annual Conference and Exposition

Copyright (C2004, American Society of Engineering Education” 
- 5 days to one week

$\circ$ Due to teacher concern to cover the SOLs

- Average students -8 days

- Gifted students -5 days

- Allow adjustability to expose the kits to the entire population

- Create an in-depth lesson plan that can have 3 options (short, middle, and long)

- Teachers can do some of the teaching before the ETK kits come to them

\section{Other}

- Questions:

- Is there a link from the middle school activities to the next level...the high school?

- Does this project anticipate the need for this, given the potential benefit and interest in engineering and problem solving?

- Comments

- I feel that working with Jason materials the lessons we go over in the in service are the ones I have the most success with

- Concerns

- Affordability of materials 